\title{
Huzurevinde kalan yaşılıarda malnütrisyon, depresyon ve yaşam kalitesi üzerine etki eden faktörlerin belirlenmesi
}

\author{
Determination of the factors affecting malnutrition, depression and quality of life in the \\ elderly residing in nursing homes
}

\author{
Dilek Karaman, Kenan Topal, Hüseyin Aksoy, Çiğdem Gereklioğlu
}

Gönderilme tarihi:25.06.2019

Kabul tarihi:03.09.2019

\begin{abstract}
Özet
Amaç: Bu çalışmada Adana Huzurevi Yaşlı Bakım ve Rehabilitasyon Merkezi'nde yaşayan yaşlıların malnütrisyon ve depresyon durumlarının belirlenmesi, yaşam kalitelerinin ölçülmesi ve bunları etkileyen çevresel faktörlerin araştırılması amaçlanmıştır.

Gereç ve yöntem: Bu araştırma Adana'da huzurevinde kalmakta olan 116 yaşlı üzerinde yapıldı. Katılımcıların sosyodemografik verileri kaydedilerek, çocuklarıyla görüşme sıklıkları, gelir algıları, huzur evinde yapılan aktivitelerin sıklığı ve katılma istekleri, verilen sağlık hizmetinden ve huzurevi koşullarından memnuniyetleri, huzurevi çalışanları ve huzurevi sakinleri ile ilişkileri beşli Likert tipi puanlama ile sorgulandı. Katılımcılarda malnütrisyon ve depresyonun belirlenmesi için MNA-SF ve GDÖ, yaşam kalitelerinin ölçülmesi için WHOOQOLOLD ölçekleri uygulandı.

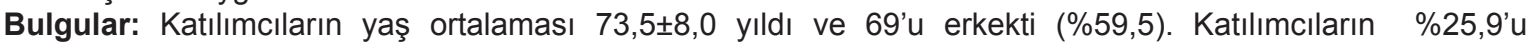
evli,\%33,6'sı az eğitimli ve \%71,6'sının en az bir kronik hastalığı vardı. Katılımcılara uygulanan MNA-SF ile 24 kişide $(\% 20,7)$ malnütrisyon riski ve 7 kişide $(\% 6)$ malnütrisyon saptandı. GDÖ ile 8 kişide $(\% 6,9)$ olası depresyon ve 32 kişide $(\% 27,6)$ depresyon saptandı. WHOQOL-OLD ile ölçülen yaşam kalitesi toplam puanı ortalaması 73,0 7,3 olarak bulundu. Kadınlarda MNA-SF puanı daha düşük, GDÖ puanı daha yüksekti. GDÖ puanı eşi ölmüş olanlarda, az eğitimli ya da ilköğretim görenlerde daha yüksekti. WHOQOL-OLD puanı orta ve daha yüksek eğitimlilerde daha yüksekti. Ölçeklerin kendi aralarındaki korelasyona göre ise malnütrisyonu gösteren MNA-SF puanı azaldıkça depresyon puanının arttığı ve depresyon puanı arttıkça yaşam kalitesi puanının azaldığı bulundu.

Sonuç: Huzurevlerinde kalmakta olan yaşlı kişilerin malnütrisyon ve depresyon durumlarının geçerli ölçeklerle kapsamlı bir şekilde değerlendirilmesinin gelecekteki sağlık problemlerini önlemek ve yaşlıların yaşam kalitesini iyileştirmek açısından çok önemlidir.
\end{abstract}

Anahtar Kelimeler: Yaşlı, yaşlı evi, malnütrisyon, depresyon, yaşam kalitesi.

Karaman D, Topal K, Aksoy H, Gereklioğlu Ç. Huzurevinde kalan yaşlılarda malnütrisyon, depresyon ve yaşam kalitesi üzerine etki eden faktörlerin belirlenmesi. Pam Tıp Derg 2019;12:545-553.

\begin{abstract}
Purpose: The aim of the study was to determine malnutrition, depression status and the quality of life in the elderly residing in a nursing home in Adana.

Materials and Methods: This cross-sectional study was conducted with 116 elderly people residing in Adana Nursing Home. The sociodemographic data of the participants were recorded and their social environment was questioned with a five point Likert-type scoring. MNA-SF and GDS were used to determine malnutrition and depression, and WHOOQOL-OLD were used to measure quality of life.

Results: The mean age of the participants was $73.5 \pm 8.0$ years and $69(59.5 \%)$ were male, $25.9 \%$ were married, $33.6 \%$ were low-educated and $71.6 \%$ had at least one chronic disease. Malnutrition risk was detected in $24(20.7 \%)$ subjects and malnutrition was detected in $7(6 \%)$ with MNA-SF. Number of the subjects with depression and possible depression were found to be $32(27.6 \%)$ and $8(6.9 \%)$, respectively according to GDS. MNA-SF score was lower and GDS score was higher in females. GDS score was higher in the elderly with a deceased spouse, and who were low educated/graduates of elementary school. WHOQOL-OLD score was higher in the subjects with intermediate/high education level. According to the correlation between the scales, depression score was found to increased MNA-SF score decreased, and quality of life score was found to decrease as depression score increased.
\end{abstract}

Dilek Karaman, Uzm.Dr. Sağlık Bilimleri Üniversitesi Adana Şehir Eğitim ve Araştırma Hastanesi Aile Hekimliği Kliniği ADANA, e-posta: dilekk_ karaman@hotmail.com (orcid.org/0000-0003-4242-0225)

Kenan Topal, Doç.Dr. Sağlık Bilimleri Üniversitesi Adana Şehir Eğitim ve Araştırma Hastanesi Aile Hekimliği Kliniği ADANA, e-posta: ktopal9@ yahoo.com (orcid.org/ 0000-0002-9681-6121) (Sorumlu yazar)

Hüseyin Aksoy, Uzm.Dr. Sağlık Bilimleri Üniversitesi Adana Şehir Eğitim ve Araştırma Hastanesi Aile Hekimliği Kliniği ADANA, e-posta: huseyinaksoy98@yahoo.com (orcid.org/0000-0002-4554-6790)

Çiğdem Gereklioğlu, Dr. Öğr. Gör. Başkent Üniversitesi Tıp Fakültesi, Aile Hekimliği Anabilim Dalı, ANKARA, e-posta: gereklioglucigdem@ hotmail.com (orcid.org/0000-0003-3556-9865) 
Conclusion: Comprehensive assessment of malnutrition and depression status of the elderly residing in nursing homes with valid scales is crucial for preventing future health problems and improving their quality of lives.

Key Words: Elderly, homes for the Aged, malnutrition, depression, quality of life.

Karaman D, Topal K, Aksoy H, Gereklioğlu Ç. Determination of the factors affecting malnutrition, depression and quality of life in the elderly residing in nursing homes. Pam Med J 2019;12:545-553.

\section{Giriş}

Organizmada hücre, doku, organ ve sistemler düzeyinde zamanın ilerlemesiyle meydana gelen, geriye dönüşü olmayan, yapısal ve işlevsel değişikliklerin tümü yaşlanma olarak ifade edilir. Çevresel faktörlere uyum sağlayabilme yeteneğinin azaldığı yaşılılık dönemi fiziksel, psikolojik ve sosyal boyutları ile bir bütün olarak değerlendirilmesi gereken bir dönemdir [1]. Dünya Sağlık Örgütü'nün (DSÖ), yaşlanma ve sağlık konusunda yayınladığı raporda yaşılıı kavramı kişinin kendi içsel kapasitesi ile uygun çevresel özelliklerin birlikteliği ile belirlenen işlevsellik merkeze alınarak yeniden tanımlanmıştır [2, 3].

Yaşlılık döneminin önemli problemlerinden birisi malnütrisyondur [4]. Malnütrisyon, yaşlıların işlevselliklerini devam ettirebilmelerinde, kaliteli yaşamalarında önemli bir etkendir. Toplumda yaşayan eve bağımlı yaşlılarda malnütrisyon görülme oranı $\% 5,8$ iken bakımevlerinde yaşayan yaşlılarda \%13,8'dir [5]. Malnütrisyonu olan yaşlılarda depresyon, kognitif fonksiyon kaybı ve fiziksel bağımlılık görülme sıklığında artış tespit edilmiştir [6]. Yaşlılıkta herhangi sebeple kilo kaybının başlangıcını takip eden yıllar içinde mortalite oranı büyük oranda artmaktadır[7]. Buyüzden heryaşı ı hasta mutlaka malnütrisyon açısından değerlendirilmelidir. Ayrıca malnütrisyona sıklıkla eşlik eden depresyon yaşam kalitesini etkileyen önemli bir faktör olarak karşımıza çıkmaktadır [8]. Yaşam kalitesi kişinin yaşadığı kültür ve değer sistemleri çerçevesinde, amaçları, beklentileri, standartları ve ilgileri ile ilişkili olarak yaşamdaki pozisyonunu algılaması şeklinde tanımlanır [9]. Birinci basamakta takip edilen yaşılıarda malnütrisyon ve depresyon durumlarını uygun ölçeklerle belirlemek, takip ve tedavilerinin doğru bir şekilde düzenlenmesi genel yaşam kalitelerinin yükseltilmesi açısından önemlidir.

Birinci basamakta hizmet veren aile hekimleri de insan hayatının çocukluktan sonra bakım gereksiniminin en yüksek olduğu bu dönemde yaşılıarın sağlığın korunması ve geliştirilmesi için çaba sarf etmektedirler [10]. Yaşı hastanın yönetiminde tıbbi, mental, işlevsel ve sosyal etkenler birlikte değerlendirilmelidir. Böylece işlevsel duruma gelen yaşlıların yaşam kalitesinin korunması ve aktif bir yaşam sürmesi de sağlanmış olacaktır.

Bu çalışmada Adana Huzurevi Yaşıı Bakım ve Rehabilitasyon Merkezi'nde yaşayan 60 yaş üstü kişilerin malnütrisyon ve depresyon durumlarının belirlenmesi, yaşam kalitelerinin ölçülmesi ve bunları etkileyen çevresel faktörlerin araştırıması amaçlanmıştır.

\section{Gereç ve yöntem}

Bu çalışma Adana Huzurevi Yaşlı Bakım ve Rehabilitasyon Merkezi'nde 01 Ocak-01 Nisan 2017 tarihleri arasında 116 huzurevi sakini üzerinde yapılan gözlemsel tipte tanımlayıcı bir araştırmadır. Katıımcıların sosyodemografik verileri ve huzurevinde kaldıkları bölüm kaydedilerekçocuklarıylagörüşmesıklıkları, gelir algıları, huzur evinde yapılan aktivitelerin sıklığı ve katılma istekleri, verilen sağlık hizmetinden memnuniyetleri, huzurevi çalışanları ve diğer huzurevi sakinleri ile ilişkileri ve huzurevi koşullarından memnuniyetleri beşli Likert tipi puanlama ile (1: en az, 5: en çok) yapılandırıımış bir anket formuyla sorgulandı. Araştırmaya en az altı aydır huzurevinde yaşamayan, demans veya alzheimer gibi kognitif fonksiyon kaybı yapan bir hastalığı olan kişiler dahil edilmedi. $\mathrm{Bu}$ araştırma için Adana Numune Eğitim ve Araştırma Hastanesi Girişimsel Olmayan Klinik Araştırmalar Etik Kurulu'nun 27.10.2015 tarihli, 207 sayılı toplantısında onay alındı ve araştırma Helsinki bildirgesine uygun olarak yürütüldü.

Mini Nutrisyon Değerlendirme Ölçeği Kısa Formu (MNA-SF): Katılımcılarda malnütrisyonu taramak için yetersiz beslenmenin erken evrede saptanmasını sağlayan MNA-SF kullanılmıştır [11]. Sarıkaya tarafından ölçeğin Türkçe geçerliliği kanıtlanmış, sensitivitesi 0,94 ve spesifitesi ise 0,81 olarak saptanmıştır. Ölçekten elde edilen sonuçlar 12-14 puan arası normal beslenmiş, 8-11 puan arasında risk altında ve 
0-7 puan arası belirgin malnütrisyon şeklinde skorlanır [12] .

Geriatrik Depresyon Ölçeği: Yaşlı hastalar için geçerli bir tarama testi olan Geriatrik Depresyon Ölçeği (GDÖ) Yesavage ve ark. tarafından geliştirilmiştir [13] . GDÖ'nün geçerlik ve güvenilirliği Ertan ve ark. tarafından yapılmıştır [14] . Birinci basamağa başvuran yaşlı hastanın depresyon açısından taranması ve incelenmesi için kolaylıkla uygulanabilen GDÖ evet-hayır şeklinde yanıtlanan 30 maddeden oluşur. Skorlama 0-10 puan depresyon yok', 11-13 puan 'olası depresyon', 14 ve üzeri puan 'kesin depresyon' şeklinde yapılır.

DSÖ Yaşlılar için Yaşam Kalitesi Ölçeği (WHOQOL-OLD): WHOQOL-OLD ölçeği, DSÖ Yaşam Kalitesi Ölçeği çalışmalarını yürüten uluslararası 22 grupla birlikte eşzamanlı olarak Türkiye'deki yaşlı topluma yönelik kullanılmak üzere Eser ve ark. tarafından geliştirilmiştir. Ülkemizde yaşlı nüfus için kullanılabilen ilk genel amaçı yaşam kalitesi ölçeğidir. Ölçek altı boyut (Özerklik, Geçmiş Bugün Gelecek Faaliyetleri, Sosyal katılım, Ölüm ve ölmek ve Yakınlık) içinde, 24 tane beşli Likert tipi sorudan oluşmaktadır. Maddelerin puanlaması; '1: hiç, 2: çok az, 3: orta derecede, 4: çokça, 5: aşırı derecede' şeklindedir. WHOQOL-OLD modülünün Türkçe sürümünün psikometrik özellikleri geçerli ve güvenilir bir ölçek olduğunu göstermektedir. Ölçeğin bir kesme puanı yoktur, daha yüksek puan daha yüksek bir yaşam kalitesini gösterir [15] .

İstatistiksel Analizler: Elde edilen verileri tanımlamak için ortalama ve standart sapmaları verildi veya frekans ve oranları hesaplandı. Katılımcıların huzurevindeki sosyal ortamla ilgili değerlendirmelerini içeren ve beşli Likert Ölçeği kullanılarak sorgulanan maddelerin skorlarının analizi test değeri 3,0 alınarak tek örneklemli $t$ testi ile yapıldı. Gruplar arasındaki karşılaştırmalar için iki örneklemli $\mathrm{t}$ testi, Oneway Anova, Kruskal Wallis ve Kikare testleri kullanıldı. Değişkenler arasındaki ilişkilerin analizi için Spearman korelasyonu yapıldı. Testlerde $p<0,05$ anlamlı olarak kabul edildi.

\section{Bulgular}

Bu çalışmaya Adana Huzurevi Yaşlı Bakım ve Rehabilitasyon Merkezi'nde yaşayan 116 kişi katıldı. Katılımcıların yaş ortalaması $73,5 \pm 8,0$ yıldı ve 69'u erkekti $(\% 59,5)$. Katılımcıların 30'u evli (\%25,9), 30'u boşanmış $(\% 25,9)$ ve 56 'sı eşi ölmüş $(\% 48,3)$ kişilerden oluşuyordu. Eğitim durumlarına göre ise 39 kişi $(\% 33,6)$ az eğitimli, 45 kişi $(\% 38,8)$ ilköğretim, 32 kişi $(\% 27,6)$ ortaöğretim ve üstü şeklinde dağılıyordu. Katılımcılardan 83'ünün $(\% 71,6)$ en az bir kronik hastalığı vardı. Katılımcılar ortalama $5,7 \pm 4,9$ yıldır huzurevinde kalmaktaydı, 64'ü $(\% 55,2)$ huzurevi ana binada, 52'si $(\% 44,8)$ bahçede bulunan küçük evlerde yaşamaktaydı.

Katılımcıların huzurevindeki sosyal ortamla ilgili değerlendirmelerini içeren beşli Likert tipi maddelerin ortalama skorlarının analiziyle elde edilen sonuçlara göre yaşıların çocuklarıyla görüşme sıklığı ortalama skoru $(3,22 \pm 1,0)$ test değeri 3,0'a göre anlamlı olarak yüksek bulunurken ( $\mathrm{t}=2,085, p=0,040)$, gelir algısı ortalama skoru $(2,45 \pm 1,0)$ test değerine göre anlamlı olarak düşük bulundu ( $\mathrm{t}=$ $5,753, p=0,000)$. Katılımcıların huzurevinde içinde bulundukları sosyal ortamlarıyla ilgili değerlendirme sorularına verdikleri yanıtların ortalama skorları ve bu skorların test değerine göre farklıııkları da Tablo 1'de verilmiştir.

Katılımcılara uygulanan MNA-SF testinin ortalama puanı $12,3 \pm 2,1$ idi. Test sonuçlarına göre 85 kişi $(\% 73,3)$ normal olarak değerlendirildi, 24 kişide $(\% 20,7)$ malnütrisyon riski ve 7 kişide (\%6) malnütrisyon saptandı. Katılımcılara uygulanan GDÖ'nün puanı ortalaması 9,3 $\pm 7,9$ idi, 76 kişide $(\% 65,5)$ depresyon yoktu, 8 kişide $(\% 6,9)$ olası depresyon ve 32 kişide $(\% 27,6)$ depresyon saptandı. Katılımcıların yaşam kalitesi WHOQOL-OLD ile ölçüldü. 'Duyusal İşlevler' alanının ortalama puanı 9,8 $\pm 2,6$,

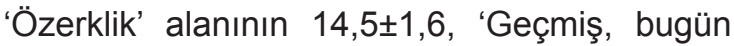
ve gelecek faaliyetleri' alanının ortalama puanı $14,1 \pm 2,1$, 'Sosyal katıım' alanının ortalama puanı 13,2 $\pm 2,5$, 'Ölüm ve ölmek' alanının ortalama puanı $6,6 \pm 3,2$, 'Yakınlık' alanının ortalama puanı $14,8 \pm 2,0$ ve toplam puan ortalaması ise $73,0 \pm 7,3$ olarak hesaplandı. Katılımcıların MNA-SF, GDÖ ve WHOQOL-OLD ölçekleri ortalama puanlarının sosyodemografik ve diğer etkisi olabilecek faktörlere göre karşılaştırılması Tablo 2'de verilmiştir.

Son olarak, huzurevinde yaşayan bireylere uygulanan malnütrisyon, depresyon ve yaşam kalitesi ölçeklerinin puanları üzerinde etkili olan faktörler ile ölçek puanlarının birbirleriyle korelasyonu yapıldı. İstatistiksel olarak 0,05 
Tablo 1. Huzurevinde kalan yaşlı bireylerin çocuklarıyla görüşme sıklığı, gelir algısı düzeyi ve sosyal ortamlarıyla ilgili değerlendirme sorularına verdikleri yanıtların ortalama puanları.

\begin{tabular}{|c|c|c|c|}
\hline \multirow{2}{*}{$\begin{array}{l}\text { Katılımcıların huzurevindeki sosyal ortamla ilgili } \\
\text { değerlendirmeler }\end{array}$} & \multirow{2}{*}{$\begin{array}{l}\text { Ortalama } \\
\text { Skor } \pm S S\end{array}$} & \multicolumn{2}{|c|}{ Test değeri 3,0** } \\
\hline & & $\mathbf{t}$ & $p$ \\
\hline - Huzurevinde çocuklarıyla görüşme sıklığı & $3,22 \pm 1,0$ & 2,0853 & $0,040^{\dagger}$ \\
\hline - Ortalama gelir algısı & $2,45 \pm 1,0$ & $-5,7531$ & $0,000^{+1}$ \\
\hline - Personelle olumlu ilişki kurma durumu & $4,31 \pm 0,5$ & 24,288 & $0,000^{+1}$ \\
\hline - Diğer bireylerle olumlu ilişki kurma durumu & $3,90 \pm 0,6$ & 15,836 & $0,000^{+\dagger}$ \\
\hline - Huzurevinde aktivite düzenlenme sıklığı & $4,44 \pm 1,5$ & 30,070 & $0,000^{+1}$ \\
\hline - Aktivitelere katılım isteği & $3,17 \pm 1,1$ & 1,6117 & 0,110 \\
\hline - Huzurevi koşullarından memnuniyet düzeyi & $4,13 \pm 0,6$ & 19,877 & $0,000^{+t}$ \\
\hline - Sağlık hizmetinden memnuniyet düzeyi & $4,12 \pm 0,6$ & 19,899 & $0,000^{\dagger+}$ \\
\hline
\end{tabular}

"Ortalama skor 1 ; en az, 5; en çok. "'Tek örneklemli t testi, test değeri 3,0 olarak alınmıştır. ${ }^{\dagger} p<0,05,{ }^{\dagger \dagger} p<0,01$.

düzeyinde anlamlı olan korelasyon katsayıları (r) tek bir yıldızla ve 0,01 düzeyinde anlamlı olanlar iki yıldızla işaretlendi (Tablo 3).

Elde edilen korelasyon analizi sonuçlarına göre:

- Huzurevi sakinlerinin yaşları arttıkça GDÖ ortalama puanı anlamlı olarak artmaktadır.

- MNA-SF puanı kadınlarda erkeklere göre daha düşüktü.

- Eğitim düzeyi arttıkça GDÖ puanı anlamlı olarak azalıyor, WHOQOL-OLD puanı artiyordu.

- Huzurevinde yaşayan bireylerin çocuklarıyla görüşme sıklığı arttıkça GDÖ puanı azalıyor, yaşam kalitesi puanı artıyordu.

- Huzurevinde yaşayan bireylerin diğer kişilerle ilişkiler arttıkça yaşam kalitesi puanı artıyordu.

- Huzurevinde düzenlenen aktivitelerin sıklığı artıkça MNA-SF puanı artıyor, GDÖ puanı ve yaşam kalitesi puanı artıyordu.

- Huzurevinde düzenlenen aktivitelerin sıklığı arttıkça MNA-SF puanı artmakta, GDÖ puanı azalmakta ve yaşam kalitesi puanı artmaktadır.

- Huzurevinde aktivitelere katılma isteği arttıkça GDÖ puanı azalıyor ve yaşam kalitesi puanı artıyordu.

- Sağlık hizmetinden memnuniyet düzeyi arttıkça GDÖ puanı azalıyordu.
Ölçeklerin kendi aralarındaki korelasyona göre ise

- MNA-SF puanı arttıkça GDÖ puanı düşüyordu.

- GDÖ puanı azaldıkça yaşam kalitesi puanı artıyordu.

\section{Tartışma}

Bu çalışmada Adana Huzurevi Yaşıı Bakım ve Rehabilitasyon Merkezi'nde yaşayan kişilerin malnütrisyon ve depresyon durumlarının belirlenerek, yaşam kaliteleri ölçülmüş ve bunları etkileyen faktörler araştırılmıştır. Araştırmamızda elde ettiğimiz verilerle huzurevinde kalan yaşlıların genel olarak eğitim seviyelerinin ve ortalama gelir algılarının düşük olduğu ve büyük çoğunluğunun en az bir kronik hastalığı olduğu bulundu. Diğer yandan çocukları ile görüşme sıklığı, huzurevinde çalışan personelle ve huzurevinde kalan diğer bireylerle olumlu ilişki kurma, huzurevinde çeşitli aktivitelerin düzenlenme sıklığı ve huzurevi koşullarından memnuniyet ise yüksek bulundu.

Manisa ve ilçelerinde bulunan huzurevlerinde kalan 130 kişi üzerinde yapılan bir çalışmaya katılanların yaş ortalaması $73,6 \pm 8,6$ yıl ve huzurevinde kalma süresi ortalaması ise $4,7 \pm 3,9$ yıl bulunmuştur. Katılımcıların \%41,5 okur-yazar değildi, \%44,7'si ilkokul ve ortaokul, \%13,8'i lise ve üzeri eğitim görmüştü, \%60'nın geliri giderini karşılıyor, \%40'ının geliri giderini karşılamıyordu ve ayrıca yaşııların \%56,9'unun en az bir kronik hastalığı vardı [16]. Benzer şekilde bizim çalışmamızda da katıımcıların yaş ortalaması 


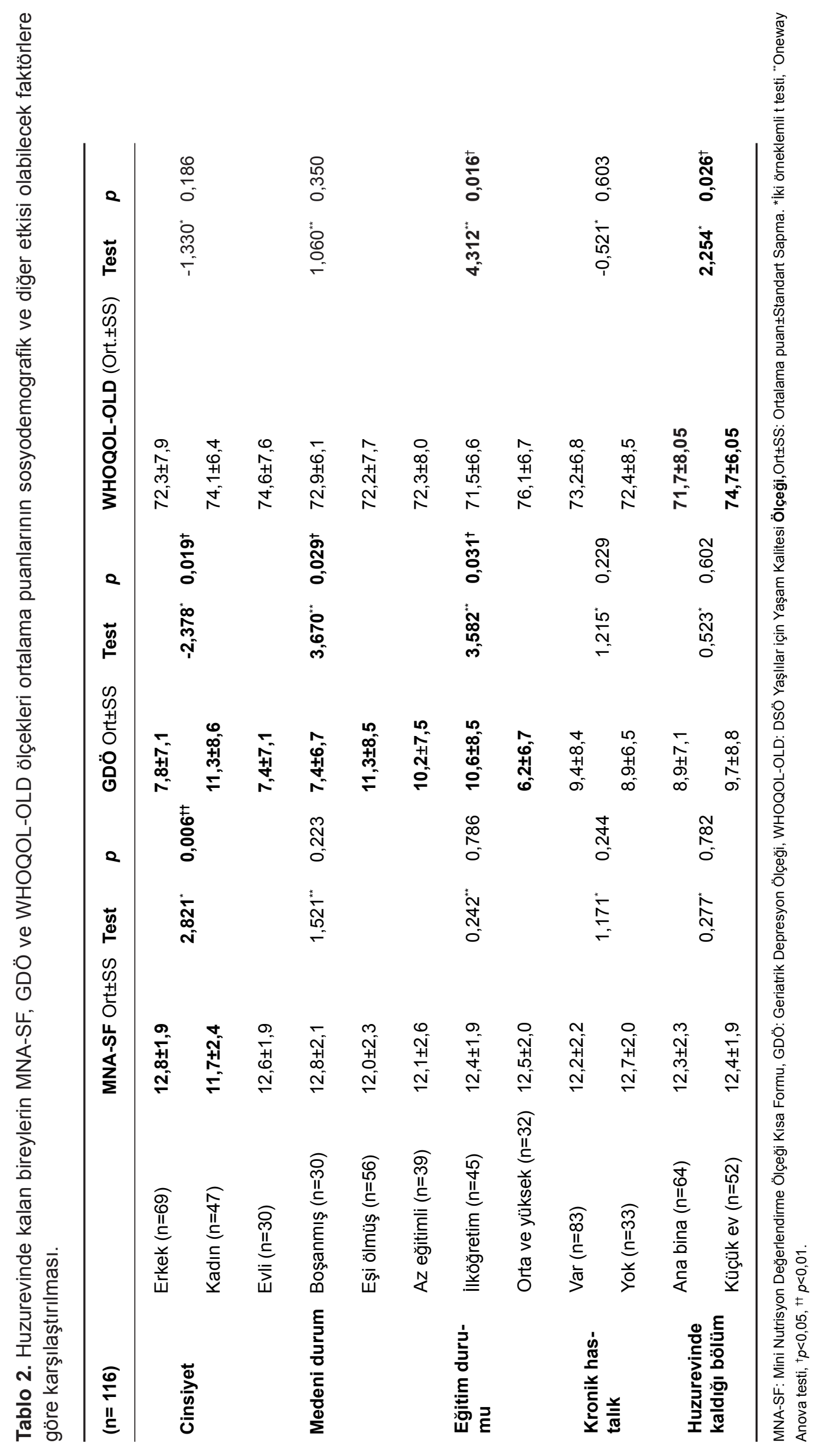


Tablo 3. Huzurevinde yaşayanlarda malnütrisyon, depresyon ve yaşam kalitesi ölçek puanları üzerinde etkili olan faktörlerin ve ölçeklerin kendi aralarında korelasyonu.

\begin{tabular}{|c|c|c|c|c|}
\hline Spearman korelasyon (r) & & MNA-SF & GDÖ & WHOQOL-OLD \\
\hline \multirow{2}{*}{ Yaş (yıl) } & $r$ & $-0,068$ & $0,199^{*}$ & $-0,062$ \\
\hline & $p$ & 0,469 & 0,032 & 0,511 \\
\hline \multirow{2}{*}{ Cinsiyet (erkek) } & r & $-0,274^{* *}$ & 0,170 & 0,137 \\
\hline & $p$ & 0,003 & 0,069 & 0,142 \\
\hline \multirow{2}{*}{ Eğitim durumu } & $r$ & $-0,010$ & $-0,231^{*}$ & $0,197^{*}$ \\
\hline & $p$ & 0,914 & 0,013 & 0,034 \\
\hline \multirow{2}{*}{ Ortalama gelir algısı } & $r$ & 0,046 & $-0,164$ & $0,307^{*+}$ \\
\hline & $p$ & 0,622 & 0,078 & 0,001 \\
\hline \multirow{2}{*}{ Huzurevinde ortalama kalma süresi } & r & $-0,055$ & $-0,049$ & 0,090 \\
\hline & $p$ & 0,558 & 0,603 & 0,338 \\
\hline \multirow{2}{*}{ Huzurevinde çocuklarıyla görüşme sıklığı } & $r$ & $-0,104$ & $-0,213^{*}$ & $0,211^{*}$ \\
\hline & $p$ & 0,317 & 0,038 & 0,040 \\
\hline \multirow{2}{*}{ Personelle olumlu ilişki kurma durumu } & r & 0,044 & $-0,039$ & $-0,021$ \\
\hline & $p$ & 0,638 & 0,675 & 0,821 \\
\hline \multirow{2}{*}{ Personelle olumlu ilişki kurma durumu } & $r$ & 0,028 & $-0,087$ & $0,247^{*+}$ \\
\hline & $p$ & 0,769 & 0,352 & 0,008 \\
\hline \multirow{2}{*}{ Huzurevinde aktivite düzenlenme sıklığı } & r & $0,243^{* *}$ & $-0,313^{* *}$ & $0,313^{*+}$ \\
\hline & $p$ & 0,009 & 0,001 & 0,001 \\
\hline \multirow{2}{*}{ Huzurevinde aktiviteler katılma isteği } & r & 0,133 & $-0,297^{* *}$ & $0,310^{* *}$ \\
\hline & $p$ & 0,155 & 0,001 & 0,001 \\
\hline \multirow{2}{*}{ Sağlık hizmetinden memnuniyet düzeyi } & $r$ & $-0,028$ & $-0,203^{*}$ & 0,143 \\
\hline & $p$ & 0,764 & 0,029 & 0,125 \\
\hline \multirow{2}{*}{ Huzurevi koşullarından memnuniyet düzeyi } & $r$ & 0,003 & $-0,060$ & $-0,035$ \\
\hline & $p$ & 0,971 & 0,523 & 0,709 \\
\hline \multirow{2}{*}{ MNA-SF } & $r$ & 1,000 & $-0,319^{* *}$ & 0,017 \\
\hline & $p$ & . & 0,000 & 0,857 \\
\hline \multirow{2}{*}{ GDÖ } & $r$ & $-0,319^{* *}$ & 1,000 & $-0,331^{* *}$ \\
\hline & $p$ & 0,000 & . & 0,000 \\
\hline \multirow{2}{*}{ WHOQOL-OLD } & $r$ & 0,017 & $-0,331^{* *}$ & 10,000 \\
\hline & $p$ & 0,857 & 0,000 & . \\
\hline
\end{tabular}

r: Spearman's rho,"Korelasyon 0,05 düzeyinde önemlidir (2 kuyruklu). " Korelasyon 0,01 düzeyinde önemlidir (2 kuyruklu). 
$73,5 \pm 8,0$ yıldı ve katılımcılar ortalama $5,7 \pm 4,9$ yıldır huzurevinde kalmaktaydı, katılımcıların \%33,6'sı az eğitimli, \%38,8'i ilköğretim, \%27,6'sı ortaöğretim ve üstü şeklinde dağılıyordu. Bu çalışmadan farklı olarak bizim çalışmamızda beşli Likert tipi puanlanan ortalama gelir algısı skoru $(2,45 \pm 1,0)$ test değeri 3,0'a göre anlamlı olarak düşük bulundu. Ayrıca yaşıların kronik hastalık oranı da daha yüksekti ve \%71,6'sının en az bir kronik hastalığı vardı.

Denizli Huzurevi'nde kalan 35 yaşlı üzerinde yapılan bir çalışmada ise çocuklarıyla görüşme sıklığı sorgulandığında yaşlıların \%40'ı hiç ziyaret edilmediğini, \%17,1'i yılda bir, \%22,9'u ara sıra ve geri kalan \%20'si ise ayda bir ya da daha fazla ziyaret edildiklerini ifade etmişlerdir [17] . İstanbul'un Avrupa yakasında bulunan üç huzurevinde 100 kişi üzerinde yapılan başka bir çalışmada yaşlıların \%17'sinin ise yılda 1 ya da 2-3 yılda $1 \mathrm{kez}$, \%32'sinin ayda 1 kez, \%27'sinin 10-15 günde $1 \mathrm{kez}$, \%24'ünün haftada 1 kez çocukları ile görüştüğü bulunmuştur. Bu çalışmada ayrıca yaşlıların \%68'inin huzurevinden her şeyi ile çok memnun olduklarını belirtmişti [18]. Bizim çalışmamızda yaşlıların huzurevinde çocukları ile genel olarak görüşme sıklığının ortalama skoru $(3,22 \pm 1,03)$ test değeri olan 3,0'dan anlamlı olarak yüksek bulundu. Yaşlıların huzurevinde çalışan personelle ve huzurevinde kalan diğer bireylerle olumlu ilişki kurma durumlarının ortalama skorları ile huzurevinde çeşitli aktivitelerin düzenlenme sıklığı ve huzurevi koşullarından memnuniyet düzeyinin ortalama skorları da test değeri olan 3,0'dan anlamlı olarak yüksek bulundu.

Pauly ve arkadaşlarının 2007 yılında yapmış olduğu bir meta-analizde; 1999-2006 yılları arasında çeşitli yaşlı bakım evlerinde MNASF ile yapılan 12 çalışmada \%2-38 arasında değişen oranlarda 'malnütrisyon', \%37-62 arasında değişen oranlarda 'malnütrisyon riski' saptandığı bildirilmiştir [19]. Saka ve arkadaşlarının İstanbul'da bir huzurevinde, malnütrisyon prevalansı ve sarkopeni ilişkisini araştırdıkları çalışmada \%38,7'sinde demans olan 349 yaşlıda MNA-SF ile \%13,5 'malnütrisyon', \%33,5 'malnütrisyon riski' tespit etmişlerdir [20]. İzmir'de bir huzurevinde yapılan başka çalışmada ise yaşlıların \%3,3'ünde 'malnütrisyon', \%20,5'inde ise 'malnütrisyon riski' bulunmuştur [21]. Benzer şekilde bizim çalışmamızda da Adana Huzurevinde kalan yaşlılarda MNA-SF ile saptanan 'malnütrisyon' $\% 6$, 'malnütrisyon riski' ise $\% 20,7$ bulunmuştur.

Depresyon yaşlılık döneminde görülen ruhsal sorunlar içinde en önde bulunur, yaşam kalitesini etkileyen önemli bir faktördür ve kilo kaybı olan yaşılıarda muhakkak araştırılmalıdır. Maral ve arkadaşları 60-74 yaş grubunda huzurevinde yaşayanlarda depresyon sıklığını \%47,6 olarak bulmuşlardır [22]. Manisa'da huzurevlerinde bulunan toplam 145 kişi üzerinde yapılan başka çalışmada \%35,9 ‘depresyon' saptanmıştır [23]. Erzurum'da bir mahallede yaşayan 60 yaş üzeri 77 yaşlı üzerinde GDÖ ile depresyon durumları değerlendirilmiş 42 kişide (\%54,5) 'depresyon' olmadığı, 7 kişide $(\% 9,1)$ 'olası depresyon' ve 28 kişide $(\% 36,4)$ 'kesin depresyon' saptanmıştır [24]. Huzurevi dışında yapılan bu çalışmaya benzer şekilde bizim çalışmamızda da GDÖ ile 76 kişide $(\% 65,5)$ depresyon yoktu, 8 kişide $(\% 6,9)$ 'olası depresyon' ve 32 kişide $(\% 27,6)$ 'kesin depresyon' şeklinde diğer huzurevinde yapılan çalışmalara göre daha düşük bir oranda saptandı.

Bir kişinin yaşamdan beklentileriyle yaşadıkları arasında fark yaşam kalitesidir diye ifade edilir. Kişiler beklentilerine ulaştıkları ölçüde yaşam kalitesi yükselirken beklentilerine uzak kaldıkça yaşam kalitesi azalır. Ankara'da bulunan üç huzurevindeki 186 yaşlı üzerinde yapılan bir araştırmada WHOQOL-OLD temel alanları puan ortalamaları 'duyusal işlevler' $15,8 \pm 3,7$, 'özerklik' $12,4 \pm 2,8$, 'geçmiş, bugün ve gelecek faaliyetleri' $11,8 \pm 3,3$, 'sosyal

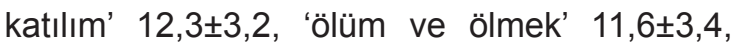
'yakınlık' 11,8 $\pm 3,2$ ve toplam puan $76,11 \pm 16,8$ olarak bulunmuştur [25]. Özellikle alt alanlarda bazı farklılıklar olmasına rağmen bizim çalışmamızda da WHOQOL-OLD temel alanları ortalama puanları 'duyusal işlevler' 9,8 $\pm 2,6$,

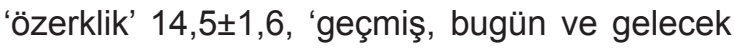
faaliyetleri' $14,1 \pm 2,1$, 'sosyal katılım' $13,2 \pm 2,5$,

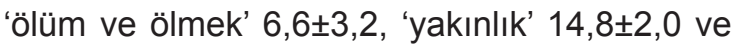
toplam puan $73,0 \pm 7,3$ olarak bu araştırmanın sonuçlarına benzer şekilde bulundu.

Yaşılıarda malnütrisyon ve depresyon ve yaşam kalitesi üzerinde etkili olan birçok faktör bulunmaktadır. Bektaş ve arkadaşlarının huzurevinde kalan 330 yaşlı üzerinde MNA kullanarak \%15,5 'malnütrisyon' ve \%35,1 'malnütrisyon riski' bulmuşlardır. Kadınlarda 'malnütrisyon' $(\% 18,8)$ ve 'malnütrisyon riski' 
$(\% 41,2)$ erkeklere göre (sırasıyla \%28,7 ve $\% 11,9)$ anlamlı olarak daha yüksek bulunmuştur [26]. Varma ve arkadaşlarının Denizli huzurevinde yaşayan yaşlılarda depresyon \%39,7 yüksek bir oranda olduğu görülmüştür. $\mathrm{Bu}$ çalışmada kadın olmak, kronik fiziksel hastalık ve çoklu ilaç kullanımının depresyon için risk faktörleri olduğu bulunmuştur [27]. Yine Zonguldak'ta yapılan bir çalışmada huzurevinde kalan yaşıılar üzerinde uygulanan GDÖ ile elde edilen ortalama puanın kadınlarda $(23,2 \pm 4,4)$ erkeklere göre $(16,5 \pm 7,2)$; sosyal aktivitelere katılmayanlarda $(23,1 \pm 5,0)$ katılanlara göre $(15,6 \pm 6,8)$ daha yüksek olduğu bulunmuştur [28]. Erkal ve arkadaşlarının Ankara'da bir huzurevinde 121 hasta üzerinde WHOQOLOLD ile yaşam kalitesini ölçtükleri araştırmada ortalama yaşam kalitesi puanları erkeklerde kadınlardan, evli olanlarda boşanmış ya da eşini kaybetmiş olanlardan, aylık geliri yüksek olanlarda aylık geliri düşük olanlardan ve eğitim seviyesi yüksek olanlarda eğitim seviyesi düşük olanlardan anlamlı olarak daha yüksek bulundu [29]. Bu araştırmalarda ulaşılan sonuçlar ile bizim araştırmamızın sonuçları benzerdi. Araştırmamızda katılımcıların MNASF, GDÖ ve WHOQOL-OLD ölçekleri ortalama puanlarının sosyodemografik faktörlere göre karşılaştırıldığında MNA-SF puanının kadınlarda erkeklere göre daha düşük, GDÖ puanının daha yüksek, WHOQOL-OLD puanı ise farklılık göstermiyordu. GDÖ puanı eşi ölmüş olanlarda evli ya da boşanmış olanlara göre daha yüksekti, az eğitimli ya da ilköğretim görenlerde GDÖ puanı orta ve daha yüksek eğitimlilere göre daha yüksekti, orta ve daha yüksek eğitimlilerde WHOQOL-OLD puanı az eğitimli ya da ilköğretim görenlere göre daha yüksekti, bahçede bulunan küçük evde kalanlarda WHOQOL-OLD puanı ana binada kalanlara göre daha yüksekti.

Bundan başka malnütrisyon, depresyon ve yaşam kalitesi puanları üzerinde etkili olan faktörlerin korelasyonu ile elde edilen sonuçlara göre kadın olmak ve huzurevinde aktivite düzenlenme sıklığının malnütrisyon üzerinde; ileri yaş, eğitim durumu, çocuklarıyla görüşme sıklığı, huzurevinde aktivite düzenlenme sıklığı ve aktivitelere katılma isteği ve verilen sağlık hizmetinden memnuniyetin depresyon üzerinde; eğitim durumu, ortalama gelir algısı, çocuklarıyla görüşme sıklığı, personelle olumlu ilişki kurma, huzurevinde aktivite düzenlenme sıklığı ve aktivitelere katılma isteğinin yaşam kalitesi üzerinde etkili olan risk etmenleri olarak belirlendi. Ayrıca ölçeklerin kendi aralarındaki korelasyona göre ise malnütrisyonu gösteren MNA-SF puanı azaldıkça depresyon puanının artığı ve depresyon puanı arttıkça yaşam kalitesi puanının azaldığı bulundu.

Sonuç olarak, ülkemizde Sosyal Hizmetler ve Çocuk Esirgeme Kurumu Genel Müdürlüğü'ne bağlı olarak 60 yaş ve üzerindeki yaşı kişileri huzurlu bir ortamda korumak, bakmak, sosyal ve psikolojik gereksinimlerini karşılamak amacıyla kurulan yatılı sosyal hizmet kuruluşu olan huzurevleri toplumda önemli bir işlev üstlenmiş durumdadır. Elde edilen bu sonuçlar huzurevlerinde kalmakta olan yaşlı kişilerin malnütrisyon ve depresyon durumlarının geçerli ölçeklerle kapsamlı bir şekilde değerlendirilmesinin gelecekteki sağlık problemlerini önlemek ve yaşılıarın yaşam kalitesini iyileştirmek açısından çok önemli olduğunu göstermektedir.

Çıkar İlişkisi: Yazarlar çıkar ilişkisi olmadığını beyan eder.

\section{Kaynaklar}

1. Beğer T, Yavuzer H. Yaşılıı ve yaşlılık epidemiyolojisi. Klinik Gelişim 2012;25:1-3.

2. World report on ageing and health. WHO library cataloguing-in-publication data. World Health Organization, 2015. ISBN: 9789240694811.

3. Beard JR, Officer A, de Carvalho IA, et al. The world report on ageing and health: A policy frame work for healthy ageing. Lancet 2016;387:2145-2154. https:// doi.org/10.1016/S0140-6736(15)00516-4

4. Omran ML, Morley JE. Assessment of protein energy malnutrition in older person, Part I: History, examination, body composition, and screening tools. Nutrition 2000;16:50-63.

5. Kaiser MJ, Bauer JM, Rämsch C, et al. Frequency of malnutrition in older adults: A multinational perspective using the mini nutritional assessment. J Am Geriatr Soc 2010;58:1734-1738. https://doi.org/10.1111/j.15325415.2010.03016.x

6. Saka B, Kaya O, Ozturk GB, Erten N, Karan MA. Malnutrition in the elderly and its relationship with other geriatric syndromes. Clin Nutr 2010;29:745-748. https://doi.org/10.1016/j.clnu.2010.04.006

7. Marton KI, Sox HC JR, Krupp JR. Involuntary weight loss: Diagnostic and prognostic significance. Ann Intern Med 1981;95:568-574. https://doi.org/10.7326/00034819-95-5-568 
8. Şahin M, Yalçın M. Huzurevinde veya kendi evinde yaşayan bireylerde depresyon sıklıklarının karşılaştırılması. Türk Geriatri Dergisi 2003;6:10-13.

9. World health organization quality of life group. Development of the world health organization WHOQOL- BREF quality of life assessment. Psychol Med 1998;28:551-558.

10. Dişcigil G. Aile hekimliği ve yaşlı sağlığı. Jour Turk Fam Phy 1997;1:29-30.

11. Kaiser MJ, Bauer JM, Ramsch C, et al. Validation of the mini nutritional assessment short-form (MNA-SF): A practical tool for identification of nutritional status. J Nutr Health Aging 2009;13:782-788.

12. Sarıkaya D. A validity study of long and short (MNASF) forms of mini nutritional assessment (MNA) test in geriatric patients. Hacettepe University Faculty of Medicine Internal Diseases Specialty Thesis Ankara, 2013,Erişim:http://www.openaccess.hacettepe. edu.tr:8080/xmlui/handle/11655/913. Erişim tarihi $11.06,2017$.

13. Yesavage JA, Brink TL, Rose TL, et al. Development and validation of a geriatric depression screening scale: A preliminary report. J Psychiat Res 1983;17:3749.

14. Ertan T, Eker E, Şar V. Geriatrik depresyon ölçeği'nin Türk yaşlı nüfusunda geçerlilik ve güvenilirliği. Nöropsikiyatri Arşivi 1997;34:62-71.

15. Eser S, Saatli G, Eser E, Baydur H, Fidaner C. Yaşlılar için dünya sağlık örgütü yaşam kalitesi modülü WHOQOL-OLD: Türkiye alan çalışması türkçe sürüm geçerlilik ve güvenilirlik sonuçları. Turk Psikiyatri Derg 2010;21:37-48.

16. Altıparmak S. Huzurevinde yaşayan yaşlı bireylerin yaşam doyumu, sosyal destek düzeyleri ve etkileyen faktörler. FÜ Sağ Bil Tıp Derg 2009:23:159-164.

17. Karaca F. Huzurevinde kalan yaşlıların hayata bakış açıları ve gelecekle ilgili beklentileri. Aile ve Toplum 2010;1:50-72.

18. Artan T, Irmak HS. Huzurevindeki yaşlıların huzurevinde yaşlanmaya ilişkin bakış açılarının değerlendirilmesi: İstanbul Bahçelievler, Zeytinburnu ve Sultangazi huzurevi örneği. Toplum ve Sosyal Hizmet 2018;29:5170 .

19. Pauly L, Stehle P, Volkert D. Nutritional situation of elderly nursing home residents. Z Gerontol Geriatr 2007;40:3-12. https://doi.org/10.1007/s00391-0070430-x

20. Saka B, Akın S, Tufan F, ve ark. Huzurevi sakinlerinin malnütrisyon prevalansı ve sarkopeni ile ilişkisi. İç Hastalıkları Derg 2012;19:39-46.

21. Bilge A, Elbay $G$, Cürgül $M$, Koru T, Şahin S. Huzurevinde yaşayan yaşlıların bedensel ve ruhsal sağlık durumları ile beslenme durumları arasındaki ilişki. Gümüşhane Üniversitesi Sağlık Bilimleri Derg 2017;6:40-45.
22. Maral I, Aslan S, İlhan MN, Yıldırım A, Candansayar $S$, Bumin MA. Depresyon yaygınlığı ve risk etkenleri: Huzurevinde ve evde yaşayan yaşılıarda karşılaştırmalı bir çalışma. Türk Psikiyatri Derg 2001;12:251-259.

23. Demet MM, Taşkın EO, Deniz F, Karaca N, İçelli I. Manisa huzurevinde kalan yaşlılarda depresyon belirtilerinin yaygınlığı ve ilişkili risk etkenleri. Türk Psikiyatri Derg 2002;13:290-299.

24. Kocataş Ö, Güler G, Güler N. 60 yaş ve üzeri bireylerde depresyon yaygınlığı. Atatürk Üniversitesi Hemşirelik Yüksekokulu Derg 2004;7;8-16.

25. Ercan Şahin N, Emiroğlu N. Huzurevinde yaşayan yaşılıarın yaşam kalitesi ve yaşam kalitesini etkileyen faktörler. Hacettepe Üniversitesi Hemşirelik Fakültesi Derg 2015;1:57-66.

26. Bektaş $Y$, Özgün Başıbüyük $G$, Çınar $Z$, Ay F, Alan A. Huzurevinde kalan yaşlılarda malnütrisyon sıklığı. Ahi Evran Üniversitesi Sosyal Bilimler Enstitüsü Derg 2017;3:339-348.

27. Varma GS, Oğuzhanoğlu NK, Amuk T, Ateşçi F. Huzurevindeki yaşlılarda depresyon sıklığı ve ilişkili risk etmenleri. Klinik Psikiyatri 2008;11:25-32.

28. Yılmaz E. Huzurevinde kalan yaşlılarda depresyon ve benlik saygısı ilişkisi. Kalem Eğitim ve İnsan Bilimleri Derg 2018;8:553-578.

29. Erkal S. Şahin H, Sürgit EB. Huzurevindeki yaşlıların yaşam kalitesi ile demografik ve kazaya ilişkin özellikleri arasındaki ilişkinin incelenmesi. Turk J Geriatr 2011;14:45-53. 